\title{
MAPPING OF DROUGHT AND FOOD INSECURITY REGION IN LEBAK REGENCY, BANTEN PROVINCE
}

\author{
M.H. Dewi Susilowati ${ }^{1}$, Adi Wibowo ${ }^{2}$, Dewi Susiloningtyas ${ }^{3}$, Ratri Candra Rastuti ${ }^{4}$ \\ ${ }^{1234}$ Department of Geography, Faculty of Mathematics and Natural Science \\ University of Indonesia \\ Email: maria.hedwig@ui.ac.id
}

\begin{abstract}
Drought and food insecurity are recurring disasters in Lebak Regency. The drought is one of the obstacles in increasing food production in Lebak Regency. The objectives of this study are (a) Making maps of the drought and food insecurity region in Lebak Regency; (b) Evaluating the relationship between regions of drought and food insecurity. The analytical method uses spatial analysis and Chi-Square correlation to determine the relationship between drought region and food insecurity region. The results of the analysis concluded that firstly, the region of very high drought levels concentrated in the northern region which was relatively near to the district capital and south (southwest) relatively far from the district capital. Second, the classification of food insecurity found in Lebak Regency is food secure, rather food secure, instead of food insecurity and food insecurity. Third, the food insecurity and instead of food insecurity region tend to be in the region of moderate drought levels. Fourth, based on food insecurity region indicators, it is found that the number of poor families and sources of clean water more determines the level of food insecurity, this can see from the most significant score compared to other indicators. Fifth, the relationship between the drought level and food insecurity region is not significant at the 0.05 level, which means that the food insecurity and instead food insecurity region are not always in the high drought region. Likewise, the region of food secure and instead of food secure is not always in a low dry region.
\end{abstract}

Keywords: Drought region, food insecurity, mapping

\section{A. INTRODUCTION}

Drought occurs due to weather conditions deviations; rainfall is lower than normal conditions, the availability of water below the needs for living needs, agriculture, economic activities, and the environment. (Mujtahiddin, 2014, Nalbantis and Tsakiris, 2008)). The occurrence of drought in an area can be an obstacle in increasing food production in an area (Blum, 2011; Jaleel et al. 2009). A shorter rainy season and low rain intensity cause a decrease in crop yields (Moreki, 2013). Decreasing yields results in problems with food shortages in an area.

Food is the primary human need for survival. Therefore the problem of food is a top priority in human development. Food insecurity is a condition of inability to obtain adequate and appropriate food for a healthy living and useful activities. Food insecurity does not only contain elements related to the state of poverty, such as the problem of scarcity of natural resources, lack, capital, poor motivation, and laziness due to inability to meet food consumption. However, it also contains dynamic elements that are related to the process of 
how the necessary food is distributed and can be obtained by each/ household through an exchange process to influence their food needs (Suhartono, 2010; Lim Younghee at, al, 2014).

The existence of food insecurity not sufficiently shown in the form of statistical data, but about poverty reduction and regional development, the distribution aspects in the dimensions of space are essential. The spatial dimension of distribution of food insecure areas in a location indicated in the geographical position on the surface of the earth, which is often called spatial information, which presented in the form of a map. Spatial data and attribute data processed with Geographic Information Systems (GIS) in digital form, an analysis that can use is spatial analysis and attribute analysis. Spatial data is data relating to spatial locations in the form of maps (O'Sullivan, D \& D.Unwin, 2003). Therefore, mapping of right food insecurity region could be used as input in the food coping strategy. In order for the poverty reduction efforts to run smoothly and sustainably, community empowerment and cooperation with other parties are needed (Astuti, Wahyuni April and Muhammad Musiyam. 2009; Astika, Ketut Sudhana. 2010).

The mapping method is done by knowing the character of the data mapped and knowing the location that mapped so that it can determine the design of the mapping. Maps are a form of scientific visualization, which is able to analyze information relations graphically, in its development with existing cartography, not only graphically, but also geometrically, which refers to the absolute position on the surface of the earth, which provides information about facts with true, interesting and easy to understand (Kraak and Ormeling, 2007; Harley, 2001).

Drought and food insecurity maps are thematic maps that visualize specific data according to the purpose of the mapping (Borden D Dent, 1999), so that accurate data is needed both from the field and from data that is already available from reliable sources. For this reason, before the map design is carried out, an evaluation survey is conducted to determine the physical and non-physical conditions. The resulting physical and non-physical data mapped into areas of drought and food insecurity as well as the direction of mitigation to be carried out. Mapping of drought and food insecurity areas compiled with Geographic Information System (GIS). GIS is an information system with data that spatial reference or geographic coordinates and can combine graphical data (spatial) with text data (attributes) objects that geographically connected on earth 
(georeference). GIS can also combine data, organize data, and conduct data analysis, which will eventually produce maps as a reference in decision making on issues related to geography.

Lebak Regency is a dry area that has a monthly and annual average rainfall below normal and most dryland agricultural activities. Lebak Regency is also a poverty pocket located in Banten Province, consisting of 28 sub-districts and divided into 345 villages, the number of poor families continues to increase. Based on BPS data in 2011, approximately 50\% of all villages classified as poor villages, and more than $50 \%$ of households classified as poor families. Livelihoods dominated by farmers, namely $>70 \%$ of the total working population (Susilowati, MHDewi S et al., 2012 and 2013). The main problem in the environment of poor families in Lebak Regency is food.

\section{B. MATERIALS AND METHODS}

\section{Determination of The Drought}

\section{Region}

The region of drought can be determined using the Brightness, Greenness, and Wetness index (Shofiyati et al. 2007). Tasseled Cap Transformation (TCT) is a mathematical formula for calculating brightness, greenness, and wetness from digital numbers in each band
1 to band 5 and band seven on Landsat TM images. This value can reflect the state of vegetation and soil, these three indices have been studied and used in agricultural, forest, ecological and landscape studies (Sheng et al., 2011).

Tasseled Cap Transformation (TCT) produces several composites that can be used to roughly measure the brightness of each pixel at ground level, namely: composites representing the greenness of pixels, and composites that represent the yellowish level of vegetation or soil moisture (Sheng et al., 2011). This composite principle is the rearrangement of channels in the spectral space (Danoedoro, 2012).

The moisture index algorithm developed by Hasan et al. (2014) in Landsat 8 OLI images for land cover mapping or other classification projects is as follows: Wetness Index $=(0.1511$ Band2 $)+(0.1973$ Band3 $)+(0.3283$ Band4 $)+(0.3407$ Band 5) - (0.7117 Band6) - (0.4559 Band7). A negative humidity index value indicates that the soil moisture level is small, while the positive humidity index value indicates high humidity or large soil water content. The humidity of objects absorb electromagnetic waves emitted from satellites; those the sharpening (transformation) of the humidity of the spectral value is higher 
(Jamil et al., 2013; Ardiansyah, 2015).

The process of making drought region models in this study are as follows: (1) Images downloaded via the earthexplorer.usgs.gov website. (2) Landsat 8 is processed to carry out a radiometric calibration process into the corrected reflectance value of the satellite sensor. (3) Then the next process is to transform pixel values into Tasseled Cap values. The matrix coefficient used is derived from the research of Muhammad Hasan Ali Baig (2014), with the value of the matrix as follows:

\begin{tabular}{|l|l|l|l|l|l|l|l|}
\hline & $\begin{array}{l}\text { LS 8 Band } \\
1\end{array}$ & $\begin{array}{l}\text { LS 8 Band } \\
2\end{array}$ & $\begin{array}{l}\text { LS 8 Band } \\
3\end{array}$ & $\begin{array}{l}\text { LS 8 Band } \\
4\end{array}$ & LS 8 Band 5 & LS 8 Band 6 & LS 8 Band 7 \\
\hline Brightness & 0.0000 & 0.3029 & 0.2786 & 0.4733 & 0.5599 & 0.5080 & 0.1872 \\
\hline Greenness & 0.0000 & -0.2941 & -0.2430 & -0.5424 & 0.7276 & 0.0713 & -0.1608 \\
\hline Wetness & 0.0000 & 0.1511 & 0.1973 & 0.3283 & 0.3407 & -0.7117 & -0.4559 \\
\hline TCT4 & 0.0000 & -0.8239 & 0.0849 & 0.4396 & -0.0580 & 0.2013 & -0.2773 \\
\hline TCT5 & 0.0000 & -0.3294 & 0.0557 & 0.1056 & 0.1855 & -0.4349 & 0.8085 \\
\hline TCT6 & 0.0000 & 0.1079 & -0.9023 & 0.4119 & 0.0575 & -0.0259 & 0.0252 \\
\hline
\end{tabular}

(4) Results from TCT produce four parameters, namely Brightness, Greenness, Wetness, and Brightness Temperature. (5) The next step is to classify 4 TCT parameters, into four classes and give weighting values. (6) The next process is overlaying the weight of 4 TCT parameters to produce a Vegetation Drought map, or in this article, it is called the drought region model.

\section{Determination of The Food Insecurity Region}

The indicators used to determine food insecurity region refer to the Food Insecurity Atlas (FIA) including; (1) Consumption to net cereal availability ratio; (2) Percentage of population below the poverty line; (3) Percentage of villages that cannot be passed by four-wheeled vehicles; (4) Percentage of villages that do not have access to electricity; (5) Infant mortality rate; (6) Percentage of malnourished children under five; (7) Percentage of population without access to clean water (clean water sources); (8) Percentage of forest area; (9) Distance of the village to the district capital; (10) Distance of the village to the sub-district capital.

The Consumption to Net Cereal Availability Ratio (rice, corn, sweet potatoes, cassava). The per capita food availability calculated by dividing the total availability of sub-district food items by the population. In order to get the same unit as daily normative consumption, the data on net availability is converted to grams and per day.

$$
\mathrm{K}=\underline{\mathrm{NRP}}+\mathrm{CP}+\mathrm{SPP}+\mathrm{CP}
$$$$
\text { Population X } 360
$$ 
$\mathrm{K}$ : Availability of food gram/person/day

RP : Rice production;

CP : Corn Production;

SPP : Sweet Potato Production

CP : Cassava Production

$\mathrm{KK}=\underline{300 \text { grams/person/day }}$ $\mathrm{K}$

$\mathrm{KK}$ :Availability of normative consumption

$\mathrm{K}$ : Availability of food gram/person/day

The percentage of the population is below the poverty line, using data on the number of poor families compared to the number of families per village.

$M=$ Number of poor families $\quad X 100 \%$ Number of families

Classification of the percentage of villages not passed by four-wheeled vehicles refers to the classification of Food Insecurity Atlas (FIA). The percentage of households without electricity calculated from the number of households without electricity divided by the number of families per village.

$L=$ Number of families without electricity $X 100 \%$ Number of families

The infant mortality rate defines as the number of infant deaths per year per 100 live birth during the year.

$$
\mathrm{B}=\underline{\text { Death of infants }} \times 100 \%
$$
Live Births

The percentage of malnourished children under five is a comparison between the Population of Child (Under
Five Years Old) malnutrition and the number of children under five.

$\mathrm{M}=\underline{\text { Children under five are malnourished }} \mathrm{X} 100 \%$

Children under Five Years Old

Based on data from village potential and basic data, it found that in one village the same water source is available, but can be different from other villages. The types of water sources in Lebak Regency consist of rainwater reservoirs, springs, dug wells, drill wells, bottled water, and pam water (drinking water company). In this study, what considered a source of clean water is from the drinking water company, while other water sources cannot be said to be clean for food and drink.

Percentage of forest area is a ratio between forest area and village area, expressed by the formula:

$$
\mathrm{H}=\frac{\text { Forest Area }}{\text { Area of Village }} \times 100 \%
$$

The district capital is the center of economic activity and the center of the main health facilities in Lebak Regency. In this study, it is assumed that the closer to the center of activity, the easier access that can be obtained for everyday life. The subdistrict capital is the center of economic activity as well as the main health facility center in the respective sub-district. The study assumed that the closer to the center of activity, the easier access that could be 
obtained for everyday life. The results of calculations from food insecurity indicators were used to determine the composite of each village. Scoring methods are used to obtain relevant and uniform values in the assessment of indicators. After scoring done, the average score will be searched, then divided by the highest score of the score used.

Table 1. Composite Values

\begin{tabular}{|c|l|}
\hline $\begin{array}{c}\text { Average } \\
\text { Category Score }\end{array}$ & \multicolumn{1}{|c|}{ Category } \\
\hline$\geq 0.8$ & Very food insecurity \\
$0.64-<0.8$ & Food insecurity \\
$0.48-<0.64$ & Rather food insecurity \\
$0.32-<0.48$ & Rather food secure \\
$0.16-<0.32$ & Food secure \\
$<0.16$ & Very food secure \\
\hline
\end{tabular}

The analysis used is spatial analysis with map overlay method and statistical analysis using Chi-Square method. Drought region obtained by lansat image processing. Correlation between drought and food insecurity regions was used spatial analysis using overlay maps between a region of drought and food insecurity and strengthened by ChiSquare correlation test. The number of contingency coefficients will express the magnitude of the correlation. Chi-Square (X2) Test tested the correlation of variables, the formula used.

$$
\begin{aligned}
& \mathrm{X} 2=\sum \begin{array}{c}
(\mathrm{O}-\mathrm{E})^{2} \\
\mathrm{E}
\end{array} \\
& \mathrm{CC}=\sqrt{\frac{\mathrm{X}^{2}}{\mathrm{X}^{2}+\mathrm{N}}} \quad \text { (Sunyoto. D, 2010) } \\
& \mathrm{X} 2 \quad=\text { Chi-Square; } \\
& \mathrm{O} \quad \text { = Frequency of Observation; } \\
& \mathrm{E} \quad \text { = Frequency of Expectations } \\
& \mathrm{CC} \quad \text { = Contingency Coefficient }
\end{aligned}
$$

The SPSS program (Statistical Product and Service Solutions) will be used to process statistical data so that it gets the value of Chi-Square (X2) and Contingency Coefficient (CC) and can interpret from the output obtained.

\section{RESULTS AND DISCUSSION}

\section{Drought Region}

Based on processed Landsat 8 images, the drought region shown in Figure

1. Figure 1 explains that the classification of low and medium drought regions in the central and eastern regions is relatively high. While the area of high drought is generally in the lowlands. Medium drought level is the largest area (45\%) in Lebak Regency and the narrowest area (15\%) in the very high regional classification. The region of very high drought levels dominates the villages in Wanasalam, Malingping and Maja Districts. While low drought levels dominate villages in Cibeber Subdistrict, Bayah, Cilograng, Cirinten, and Sobang. 


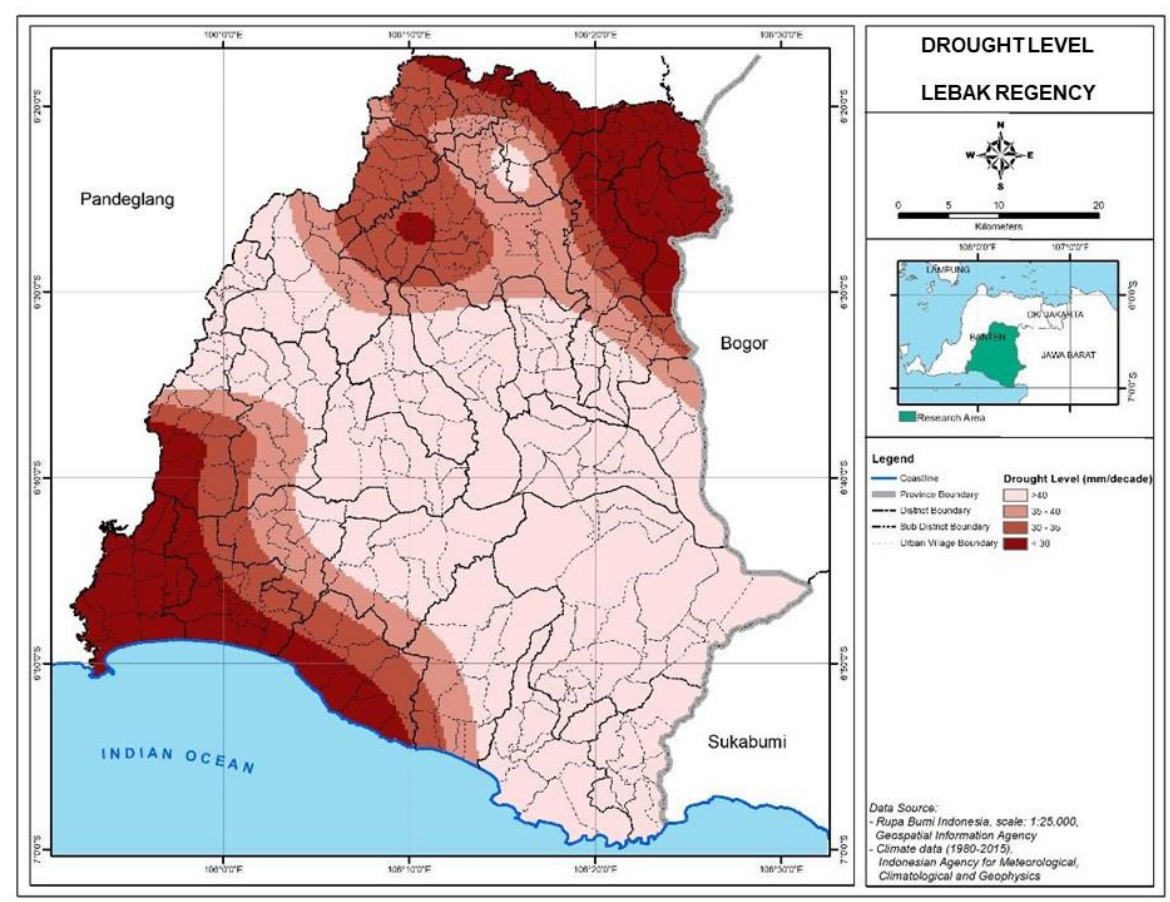

Figure 1. Model of Drought Level in Lebak Regency

\section{Food Insecurity Region}

Ten indicators, namely determine food insecurity region:

1) Consumption to Net Cereal Availability Ratio

Calculation of this ratio is used to measure the level of food consumption of the population and the level of ability of an area (village) in providing food to meet the needs of the population. If food availability is higher than the amount of consumption, then the area is considered a food surplus. If food availability is lower than consumption, then the area is a food deficit.

The villages belonging to the deficit area are in the District of Rangkasbitung. This condition can see from the low number of food production and the large population. Rangkasbitung District capital of Lebak Regency with agricultural activities are relatively small compared to other districts.

Lebak Regency dominated by highly surplus areas covering 24 subdistricts or $85.7 \%$ of all sub-districts in Lebak Regency. The condition of the villages in this sub-district has high food production, and the area of food agriculture is relatively more full compared to the villages in Kecamatan Rangkasbitung, Cibadak, Kalanganyar. The population density in the villages located in the north is denser than in the southern villages, which are relatively far from the district capital. Rare 
population density indicates the availability of land for agricultural activities is relatively broad compared to villages that have a dense population density.

2) Percentage of the population below the poverty line

The poor population measured by pre-prosperous families and level 1 families in Lebak Regency have a high percentage. In Banjarsari District there is a percentage of poor families of $64 \%$, meaning that more than half of the population is poor. In this sub-district, there are two villages with poor families above $80 \%$, namely Taman Sari village $(87 \%)$ and Ciruji village (86\%). The smallest percentage of poor families in this subdistrict is Kaduhauk village (42\%). However, the village with the most impoverished families is Kanekes village $(90 \%)$ in Lauwidamar District. The village with the least percentage of poor families is the Keduagung Tengah village (21\%) in Cibadak District.

3) Percentage of villages that cannot be passed by four wheels

Road access is an indicator of the level of economic development in a region. The absence of road access illustrates the isolation of an area and indicates a lack of public services in the area. Almost all villages in Lebak
Regency can traverse by four-wheeled vehicles; there is only one village that cannot be passed by four-wheeled vehicles, namely Kanekes Village, Leuwidamar District. The village is a Baduy tribal residence that refuses motorized vehicles to enter the area because it has a culture that is categorically different from other villages.

4) Percentage of villages that do not have access to electricity

Access to electricity is an indicator of the level of the economic capacity of a household. Also, the absence of access to electricity reflects the isolation of a region and indicates a lack of public services in the area. The percentage of not having access to electricity in Lebak Regency classified as quite high to very low. The high information means that there are households that do not have electricity in the village. Based on the data, it turns out that not all households in Lebak Regency have used electricity. There is one village that does not have access to electricity, because the village is a place where Baduy tribes live which has a different culture than other villages.

5) Underweight Nutrition

Nutrition is a condition where humans do not have nutrients needed by 
the body due to lack of food intake.

Nutritional status is an overview of the overall reflection of the use of food consumption and use of the body (Jonny, 2005; Sunarti, 2004). Assessment of the nutritional status of children under the national standards issued by the Indonesian Ministry of Health uses weight/age using the classification of malnutrition, malnutrition, good nutrition, overnutrition (Ministry of Health, Republic of Indonesia 2011; Ministry of Health, 2013).

The population of child (under five years old) malnutrition in Lebak Regency, most of the villages classified as low $(<31 \%)$, there are no villages with very high classification. However, there are villages with high classification (50 - 55\%), namely Cikamunding village, Cilograng subdistrict.

6) Infant Mortality Rate

The infant mortality rate in this paper is a number that shows the number of infant deaths aged $<1$ year from every 100 live births in 2015. The infant mortality rate in Lebak Regency is relatively low, all villages in the classification class are low, even some villages have no infant mortality. This low infant mortality rate is due to the improvement of adequate health facilities.

7) Percentage of population without access to clean water

Access to clean water is a basic necessity of the population so that it can improve the quality of life through increasing the absorption of nutrients by the body. In Lebak Regency, it is seen that only a few villages (2\%) have access to clean water by using sources from pam water (drinking water company). The clean water source of pam water (drinking water company) is only used by residents in the District of Rangkasbitung or around the capital of Lebak Regency. Residents who use water sources from springs concentrated in the east around the highlands. While the source of the dug water used by residents living in the west, south, and north, residents, who use drill well water sources concentrated in the northern part, especially villages located in Rangkasbitung, Kalanganyar, and Cibadak Districts. The only population that still uses rainwater sources is one village, namely Bejod Village, including in Wanasalam District.

8) Percentage of Forest Area

The percentage of forest area obtained from the map of Lebak Regency land use. The forest area in 
Lebak Regency is 73317.19 ha or $22.18 \%$ and the widest in Cibeber District (16967.90 ha). The forest plants spatially tend to dominate villages in the south such as Cibeber, Cigemblong, Cihara, Cijaku, Cilograng, Cipanas, Cirinten, Lebakgedong, Malingping, Panggarangan, and Sobang whereas areas that do not have forests tend to be in the northern villages relatively close to the capital of the district, such as villages in the Rngkasbitung District, Maja, Kalangnganyar, Warunggunung, Cibadak, Curugbitung, Cimarga, Cileles, and Muncang.

9) The distance of the Village to the Capital District

The distance in question is the length of the road taken from the capital of the district, namely the District of Rangkasbitung to each village. Based on the calculation, it found that the short distance to the district capital was $<10$ $\mathrm{km}$ and very far $>100 \mathrm{~km}$. From the data obtained, 6 distance classes are made, which are near, rather close, medium, a little far, far, and very far away. As many as $11 \%$ of villages are close to the district capital, $16 \%$ of villages located far from the district capital, and $20 \%$ of villages are very far from the district capital.
10) The distance of the Village to the Capital District

The distance referred to is the length of the road taken from the subdistrict capital to each village in the subdistrict. Based on the calculation, it found that the short distance to the capital of the sub-district was $<5 \mathrm{~km}$ and very far> $25 \mathrm{~km}$. From the data obtained, it made 6 close distance classes, rather close, medium, a little far, far, and very far away. $35.7 \%$ of villages located close to the sub-district capital, $2.6 \%$ of villages located far from the sub-district capital, and $1.4 \%$ of the villages are very far from the capital city of the district.

Based on the analysis of the 10 indicators, it shows that most villages in Lebak Regency belong to the preferable food secure classification class, namely 283 villages $(82 \%)$, while those who classified as rather food insecurity are 54 villages (15.7\%) and food-insecure region was Kanekes village, Leuwidamar sub-district (Figure 2). A village is a place where Baduy tribes live, which has a different culture than other villages.

Villages in the northern part of the city relatively close to the district capital tend to be in the class of food secure regions and instead of food secure 
regions. While the classification of in the southern part, which is relatively rather food insecurity region tends to be far from the district capital.

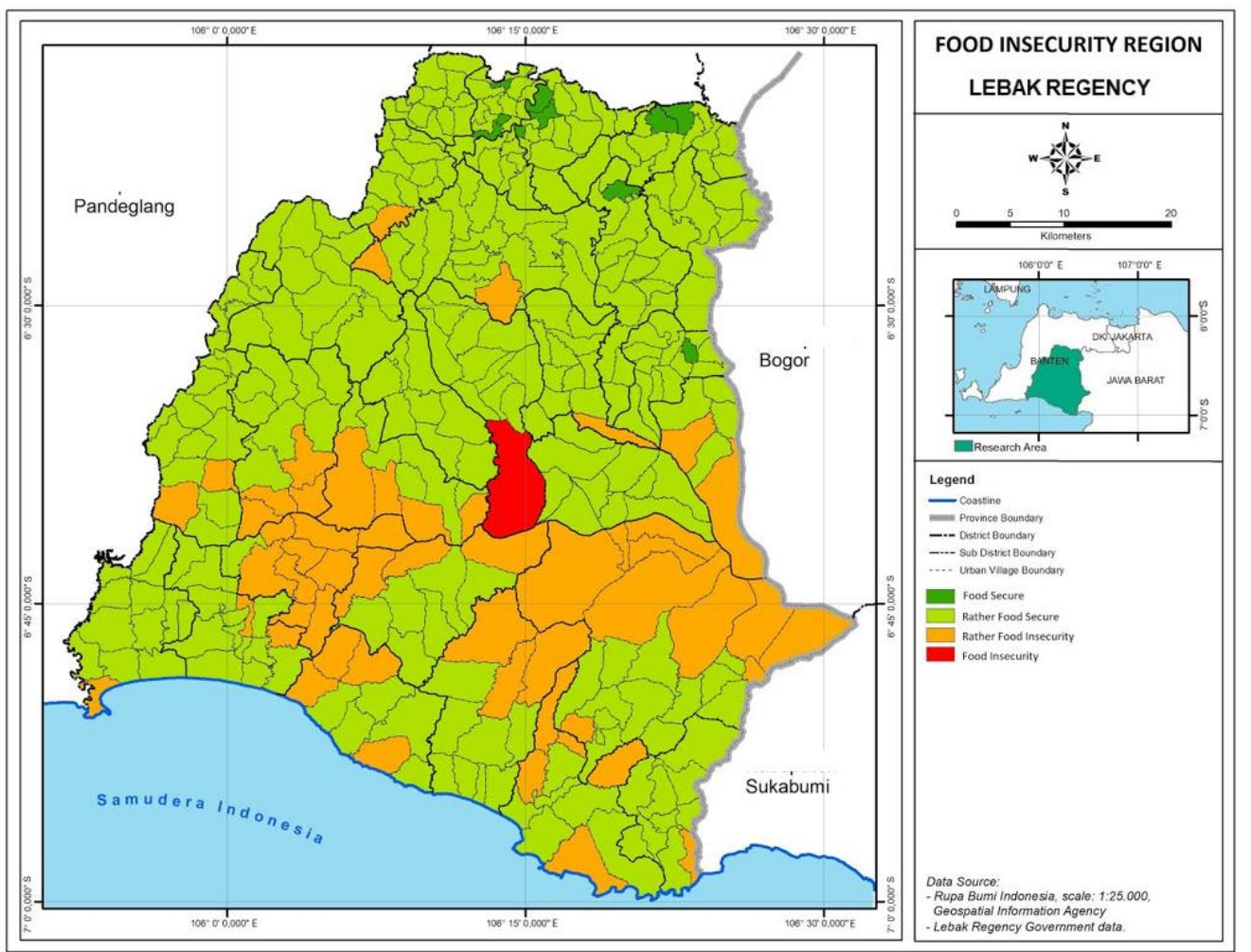

Figure 2. Food Insecurity Region in Lebak Regency

\section{The relationship between Food}

\section{Insecurity and Drought Levels}

Based on spatial analysis with map overlays shows that food insecurity region and rather food insecurity region are not always at high drought levels. Likewise, food-secure region and rather food secure region do not always have low drought levels. In table 2. shows that food insecurity region and rather food insecurity region tend to be in the area of moderate drought levels. While the food secure and rather food secure region tend to be in the area of moderate to very high drought levels.

Table 2. Food Insecurity * Level of Crosstabulation Dryness

\begin{tabular}{|l|r|r|r|r|r|}
\hline & \multicolumn{4}{|c|}{ Drought Levels } & \multirow{2}{*}{ Total } \\
\cline { 2 - 5 } & Low & Medium & High & Very High & \multicolumn{1}{c|}{7} \\
\hline Food Secure & 0 & 1 & 5 & 1 & 283 \\
Rather F Secure & 26 & 121 & 76 & 60 & 54 \\
Rather F Insecurity & 3 & 34 & 11 & 6 & 1 \\
Food Insecurity & 0 & 1 & 0 & 0 & 345 \\
Total & 29 & 157 & 92 & 67 & \\
\hline
\end{tabular}


This supported by chi-square statistical analysis showing that there is no significant correlation at the real level $(\alpha)$ of 0.05 . The magnitude of the correlation (cc) between these variables is relatively small (0.215).

Table 3. Symmetric Measures for Food Insecurity \& Drought

\begin{tabular}{|c|c|c|}
\hline & Value & $\begin{array}{c}\text { Approximate } \\
\text { Significance }\end{array}$ \\
\hline $\begin{array}{c}\text { Nominal by Contingency } \\
\text { Nominal } \\
\text { N of Valid Cases }\end{array}$ & .215 & .055 \\
\hline
\end{tabular}

\section{CONCLUSIONS}

The results concluded that firstly, the region of very high drought levels concentrated in the northern region which was relatively near to the district capital and south (southwest) relatively far from the district capital. Second, the classification of food insecurity found in Lebak Regency is food secure, rather food secure, rather food insecurity and food insecurity. Third, the food insecurity and instead of food insecurity region tend to be in the region of moderate drought levels. Fourth, based on food insecurity region indicators found that the number of poor families and sources of clean water more determines the level of food insecurity, based on the most significant score compared to other indicators; Fifth, the relationship between the drought level and food insecurity region is not significant at the 0.05 level, which means that the food insecurity and rather food insecurity region are not always in the high drought region.
Likewise, the region of food secure and instead of food secure is not always in a low dry region.

\section{E. ACKNOWLEDGMENT}

This research funded by the Directorate of Research and Community Service, Directorate General of Research and Development Strengthening the Ministry of Research, Technology and Higher Education. On this occasion we would like to thank Chancellor of The Indonesia University, Directorate of Research and Community Engagement, The Dean of Faculty of Mathematics and Natural Science, Chair of the Department of Geography, the Regional Government of Lebak Regency and the community who have assisted us in completing this research.

\section{F. REFERENCES}

Astuti, Wahyuni April dan Muhammad Musiyam. 2009. Kemiskinan dan Perkembangan Wilayah di Kabupaten 
Boyolali. Forum Geografi, Jurnal Geografi UMS, vol. 23, No. 1 Juli 2009. Surakarta, Jawa Tengah.

Astika, Ketut Sudhana. 2010. Budaya Kemiskinan di Masyarakat; Tinjauan Kondisi Kemiskinan dan Kesadaran Budaya Miskin di Masayrakat. Jurnal Ilmiah FISIP, Vol. 1, No 01, Tahun 2010.

Ardiansyah. (2015). Pengolahan Citra Penginderaan Jauh Menggunakan ENVI 5.1 dan ENVI LiDAR (Teori dan Praktek). Jakarta: PT. Labsig Inderaja Islim.

Blum, A. 2011. Breeding for Water-Limited Environments. DOI 10.1007/978-144191-41 @ Springer Science+Businees Media. LLC 201. Doi;10.1093/jxb/ert016

Borden D Dent, 1999. Cartography, Tematic Map Design. WCB Publisher, London

Badan Pusat Statistik. 2011. Perhitungan Angka Kemiskinan BPS VS World Bank. Download Center, Sensus Pedusuk 2010, tanggal 26 April 2011, jam 14.58. Jakarta.

Danoedoro, P. 2012. Pengantar Penginderaan Jauh Digital. Yogyakarta: Andi Offset.

Dymond, C. C., Mladenoff, D. J., dan Radeloff, V. C. 2002. Phenological Differences in Tasseled Cap Indices Improve Deciduous Forest Classification. Remote Sensing of Environment, 80(3), 460-472.

Depkes RI. (2011). Bagan Tatalaksana Anak Gizi Buruk. Jakarta: Departemen Kesehatan

Depkes RI (2013). Riset Kesehatan Dasar (Riskesda, 2013), Badan penelitian dan Pengembangan Kesehatan. Jakarta: Depkes RI

Harley, JB. 2001. The New Nature of Map, John Hopkins UP, Baltimore

Hasan, A. B. M., Zhang L., Shuai, T., Tong, Q. 2014. Derivation of a Tasselled Cap Transformation Based on Landsat 8 At-Satellite Reflectance. Remote Sensing Letters, 5:5, 423-431.
Jaleel C. A., P. Manivannan, At.al 2009. Drought Stress in Plant; A Review on Morphological Characteristics and Pigment Composition. International Journal of Agricultural \& Biology. ISSN

Online; http://www.fspublishers.org

Jamil, D. H., Tjahjono, H., Parman, S. 2013. Deteksi Potensi Kekeringan Berbasis Penginderaan Jauh Dan Sistem Informasi Geografis di Kabupaten Klaten. Geo Image 2 (2) (2013) Geo Image (Spatial-Ecological-Regional) Jurusan Geografi, Fakultas Ilmu Sosial, Universitas Negeri Semarang.

Jonny, 2005, Pengelolaan Lingkungan Sosial. Jakarta: Yayasan Obor Indonesia

Kraak, Menno Jan \& Ferjan Ormeling, 2007, Kartografi : Visualisasi Data Geospasial, UGM Press Yogyakarta.

Lim Younghee at, al, 2014 Payday Loan Use, and Consumer Well-Being: What Consumers and Social Workers Need to Know About Payday Loans. Journal of Poverty Volume 18, Issue 4, 2014

Mujtahiddin, M.I. 2014. Analisis Spasial Indeks Kekeringan Kabupaten Indramayu. Jurnal Meteorologi dan Geofisika, Vol. 15, No. 2 Tahun 2014: 99-107.

Moreki, J.C., \& Tsopito, C.M., 2013. Effect of Climate Change on Dairy Production in Botswana and Its Suitable Mitigation Strategies. Online Journal of Animal and Feed Research Volume 3. Issue 6: 216-221.

Nalbantis, I., \& Tsakiris, G., 2009. Assessment of Hydrological Drought Revisited. Water Resour Manage (2009) 23:881897, Springer.

O'Sullivan, D\&D.Unwin,2003. Geographic Information Analysis. John Wiley \& Sons. Inc.

Raharjo, Puguh Dwi. 2010. Teknik Penginderaan Jauh dan Sistem Informasi Geografis untuk Identifikasi Potensi Kekeringan. Jurnal Makara Seri Teknologi. Universitas Indonesia, Vol. 14 No. 2 November 2010, Hal. 97. 
105. Terakreditasi Dikti No.110/DIKTI/Kep. $/ 2009$.

Sheng, L., Feng, J.H., Lu, X.T., 2011. A Tasseled Cap Transformation for CBERS-02B CCD Data. Journal of Zhejiang University Science B. 12(9): 780-786.

Shofiyati, R., dan Kuncoro. 2007. Inderaja untuk Mengkaji Kekeringan di Lahan Pertanian (Remote Sensing for Drought Assessment on Agricultural Land). Informatika Pertanian 16 (1): 923-936.

Sunarti, 2004.Mengasuh Dengan Hati. Jakarta: Elex Media Kompetindo.
Sunyoto, D. (2010). Uji khi kuadat \& regresi untuk penelitian. Graha Ilmu:Yogyakarta.

Susilowati MH.Dewi S, dkk 2012 dan 2013. Pemetaan Kantong Kemiskinan dan Potensi Wilayah Untuk Pemberdayaan Keluarga Miskin di Kabupaten Lebak, Provinsi Banten, Hibah Stranas, Universitas Indonesia.

Suhartono, 2010. Indikator dan Pemetaan Daerah Rawan Pangan dengan mendeteksi kerawanan Pangan di Kecamatan Tanjung Bumi Kabupaten Bangkalan. Jurnal Embryo, Vol 7, No 2, Desember 2010 